\title{
Perceptions of English Teachers at Korean Universities Towards using Learning Management Systems During COVID-19
}

\author{
Stuart Jones', Andrew Richards², Cho, Youngsang ${ }^{3}$ \\ ${ }^{1}$ First author, Assistant Professor, Dankook University, stu11@hotmail.com \\ 2Corresponding author, Assistant Professor, Dankook University, andyrichards@hotmail.com \\ ${ }^{3}$ Co-author, Associate Professor, Dankook University, 03choy@gmail.com
}

\section{Abstract}

The purpose of this study is to examine the feelings and perceptions of English teachers at Korean universities towards using an LMS to teach English classes during the global COVID-19 pandemic of 2020. Data were collected from 22 teachers working at 9 different universities in the greater Seoul area. A survey questionnaire consisting of a combination of multiple choice, Likert scale and opened ended questions was used as the primary data collection method. In addition, if consent was given, survey participants were contacted via e-mail or Zoom to discuss responses in greater detail. Data analysis was done using general qualitative analysis and discussed using descriptive statistics. The findings of the study show despite the confusion caused by the pandemic, English teachers at Korean universities were able to adapt quickly to using an LMS as their main teaching interface and were generally satisfied with the LMS they used. In addition, any training received on how to operate the LMS was found to be helpful although more training in specific areas appears to be desired. Specific functions provided by LMSs for language teaching were also deemed to be important. Administrational and educational implications of these findings as well as limitations are also discussed.

Key Words: EFL, COVID-19, LMS, General English Education

1. Introduction

2. Literature Review

3. Method

4. Results and

Discussion

5. Conclusion and Implications

6. Limitations 


\section{Introduction}

The global pandemic during 2020/1 presented countless challenges throughout the education sector. High risk of virus transmission through close contact and proximity with others meant regular style lessons held in brick-andmortar classrooms were no longer viable. To protect students and faculty members, and to continue the students right to learn, decisions were made to move classes online. In Korean tertiary education, this drastically affected how all classes were to be taught, including English as a foreign language (EFL) classes, which are often part of university curricula. This presented a number of concerns for both students and faculty members. At the start of the online semester in March 2020, over $80 \%$ of students expressed concerns with the quality of classes conducted online and more than 80.3 percent of students who participated in a survey wanted a partial refund on their tuition fee due to dissatisfaction with the quality of lessons (Bakh, 2020). Furthermore, instructors who were accustomed to teaching face to face in a classroom environment were now forced to work remotely, with many having no previous experience in teaching online (Back, Kalenzi, \& Yim, 2020).

The natural solution was to use information communication technology (ICT) to maintain contact between teachers and students, provide lesson content, and share other important information. One type of ICT that would help with this is a learning management system (LMS). This is either website or application based which acts like a virtual classroom and offers a place where students and teachers can connect with each other. According to Turnbull, Chugh, and Luck (2019), the function of an LMS is to "provide an interactive online learning environment and automate the administration, organization, delivery, and reporting of educational content and learner outcomes." (p.1). There are a variety of different LMSs currently available that offer different types of interfaces and functionality, some of which require either an initial purchase or a monthly subscription fee, for example Canvas or Moodle, and others which are free for both teachers and students to use, of which Edmodo and Google Classroom are two common examples.

This pandemic and the resulting sudden government imposed social distancing levels and lockdown protocols has meant LMSs have become an essential tool for the continuation of education (Maske, 2020). Unexpectedly, instructors and students were forced to work in virtual classrooms. Online learning became the norm with little preparation and guidance. This transition presented several problems and placed instructors under pressure who previously have only conducted their classes in the traditional classroom manner (Zawacki-Richter, 2020).

COVID-19 presented a unique set of circumstances that began both quickly and unexpectedly. Teachers had no choice but to rely on LMSs as their primary medium of instruction and instead of using LMSs as supplementary resource, they now became the only practical tool available to continue classes and maintain students learning. Despite the development of several vaccines in late 2020 and subsequent global rollout in early 2021, the time frame on when life may return to normal is still unclear. Additionally, Dodds (2019) predicted that pandemics similar to the current one in the future are a strong possibility. Thus, there is a likelihood that classes could once again be taught virtually in the foreseeable future and the situation could possibly recur in coming years / decades.

As a result, this study was designed to examine general satisfaction levels amongst university English teachers in Korea of conducting LMS based EFL classes. In addition, this project will attempt to understand how prepared these teachers felt they were to use LMSs full time and how any shortfalls in training were overcome. The final aim of this research is to investigate which general features of LMSs did teachers like or dislike regarding teaching EFL classes online. 


\section{Literature Review}

\subsection{Overview of LMSs}

The use of LMS in education is not a new concept and was first introduced approximately 60 years ago with the development of the first computer aided learning system, known as PLATO (Rhode, Richter, Gowen, Miller, \& Wills, 2017). Steady advancements in LMS technology were made over the following years; however, these basic systems were limited to standalone computers, and it was not until the birth of the World Wide Web in 1982 that LMS technology really began to grow (Sharma, 2017). As with many other industries, the education sector has benefited greatly from the advancement of technical innovations and LMSs became both more popular and widely available (Hill, 2017). Over the past 10-15 years, the majority of educational institutes, in countries which have the technical infrastructure in place, have attempted to make LMS technology available to lecturers (Jurrado, Petterson, Gomez, \& Scheja, 2014). Furthermore, according to research conducted by the Educause Center for Analysis and Research in 2014, 99\% of higher educational institutions have an LMS structure in place, and they are used by $85 \%$ of teaching staff and by $83 \%$ of students. Other research (Butakov et al., 2013; Klobas \& McGill, 2010; Paulsen, 2003; Weaver et al., 2008) has identified a clear push to make LMS use a more common part of the education process. Consequently, it is logical to sugges LMSs are now an important part of the modern-day classroom. The students and teachers' needs are changing and the introduction of LMSs provides an array of functions to help facilitate learning (Bouchrika, 2020).

However, despite their increasing availability, popularity, and functionality, there appears to be some reluctance to rely on them as the sole method of communication, class management and assessment and they have mainly been used in parallel with regular face to face classes (Bervall and Umar, 2018). Furthermore, a number of previous studies (Brooks \& Pomerantz, 2017; Jenkins,
Browne, Walker, \& Hewitt, 2010; Rienties and Townsend, 2012) have shown faculty members who do opt to use LMSs, only use them for general administrative tasks, such as posting class syllabi, uploading important dates, and digitally collecting homework assignments.

Clearly the COVID-19 pandemic will have greatly altered how teachers integrate LMSs into their classes with them suddenly becoming the primary interface between teacher and learner. Since there is currently a wide range of LMS available for teachers to use and many of them will have somewhat similar functions and features, a more appropriate approach would be to generally analyze teachers liked or disliked about their LMSs to establish any common limitations or useful features.

\subsection{Teacher Satisfaction with using LMSs}

As suggested by Hooser (2018), for teachers to feel they are successful with using an LMS, they must be satisfied with the features and functions it provides. A teacher is more likely to provide higher quality lessons, which subsequently are more beneficial to students, if he or she gets satisfaction using it. Since their use in higher education became more prevalent, there have been several studies which have examined how satisfied teachers are with them. In a 2015 literature review of predictors of e-learning satisfaction in teaching, Cheok \& Wong summarized there were three main distinct areas which contribute towards user satisfaction. The first of these was user-related factors, including anxiety, attitude and self-efficacy. The second was organizational based in and referred to areas such as training, technical support, and management support. The final area was concerned with system related factors, such as ease of use, perceived usefulness, and accuracy. A similar study by Al-Busaidi and Shihi (2012) concluded experience with using technology, personal innovativeness, system quality, and training were all factors in determining satisfaction with an LMS for instructors at a university in Oman. A further study by Holmes \& Rodriguez (2018) of students and 
teachers in higher education in Australia concluded the inability to track student interaction with course materials posted on the LMS led to a feeling of dissatisfaction amongst teaching staff. Furthermore, teachers in this study also expressed concern about the lack of standardization of organization on the LMS. Not every teacher was using the same LMS, and those who were chose to upload and deliver content differently, potentially causing confusion for the students. This study continues by noting teaching staff were somewhat cautious of the tools provided by the LMS, particularly with large classes which led to a significant amount of time being spent reviewing and responding to students' work online. Other research carried out by the University of Colorado in 2016 reported that while the level of teacher satisfaction with the LMS was generally quite high, there were worries about possibly having to migrate to a different LMS system in future, meaning all work would have to be transferred and staff would have to learn how to use a new system.

In studies more specific to language teaching, Basal (2015) found English teachers in Turkey were generally positive about using an LMS in their English classes, albeit in conjunction with face-to-face classes and not as the standalone medium of interaction. Wulandari and Budiyanto (2017) suggest teachers feel the use of an LMS in an English class would be beneficial at university level English. Ushakov (2017) builds on this idea by commenting on the notion that teachers feel an LMS provide English learners with the ideal platform to develop communication skills. Learners can use tools often included in LMSs such as online discussion boards to communicate freely and with less anxiety and embarrassment than if speaking to someone face to face.

Whilst all the studies mentioned above have clarified what affects teacher satisfaction with LMS, all of them were conducted pre-COVID-19. Given the current increased reliance on LMSs, it is logical to suggest differing factors may now be involved with using LMSs and it could be important to learn if and how the pandemic has affected satisfaction levels.

\subsection{Importance of LMS Training}

One of the most important decisions teachers had to make when it was announced classes would be online, was which LMS to use. As mentioned previously, there are a number of different ones available, some free and some not, and teachers had to quickly adapt to the system and figure out how to implement it. However, instructors could have differing levels of digital competency and with all the various LMSs available and such a short window to become familiar with its functions, it would be assumed some form of training would be required. Institutions would have to plan, provide, and execute the training but could be burdened with financial and administrative challenges. (Karunaratne, Zhemchugova, Byungura, and Olsson. 2019).

Nonetheless, one study (Cabral, Pedro \& Gonçalves, 2012) looked at the significance of faculty training pre-COVID era. It described the importance of faculty members attending workshops to develop their skills needed to use LMS functions. The study concluded that faculty members who attended no workshops had courses with limited activity. Those who participated in one or two workshops had enough fundamental knowledge to use the basic functions of the LMS. However, attendees of three or more workshops had superior knowledge of technical ability thus producing higher levels of competency in the use of the LMS and its functions. Furthermore, additional research (Karunaratne, Zhemchugova, Byungura, and Olsson. 2019) emphasized the importance of careful planning, delivery and purpose of focus are necessary even before training of the LMS can be carried out to provide the instructors with the relevant skill set and competency in the digital era.

Consequently, this research will attempt to discover if EFL instructors in Korean universities were prepared enough to use an LMS during the COVID pandemic and how did their respective institutions deliver training, if they did at all. 


\subsection{Strengths and Weaknesses of LMSs}

The benefits of using LMSs in higher education are extensive and are not only essential, but a compulsory part for education to continue during the COVID-19 pandemic. Undoubtedly, the main advantage is learning is not confined to the four walls of a classroom, but it is mobile, having no restrictions on time and space (Chaubey \& Bhattacharay, et al., 2015; Epping, 2010). Moreover, a great majority of LMS platforms are accessible from computers, tablets and smartphones often having their own applications in addition to websites. This flexibility for both instructors and learners allows them to access class materials anywhere, anytime, promoting communication away from the classroom via discussion forums, real time messaging and video conferencing, email and announcements posts (Rhoads \& Stachowiak, 2018) Adding to this, Wulandari \& Budiyanto (2017) stated EFL learners in higher education would benefit from discussion forums to improve their speaking skills and collaborative learning due to lower levels of anxiety and stress than if they were in a regular classroom. The study also discovered through teachers' guidance and facilitation, assisted with the various LMS functions, the combination could improve students' weaknesses in various aspects of the four English skills. Further research compiled during the COVID pandemic (Dias, Hadjileontiadou, Diniz et al., 2020) shows personalized feedback learners received from their instructors increased their interaction with the LMS and class content, which proved to show an increase in learners overall learning performance outcomes.

However, there are some drawbacks as a recent study in Romania during the pandemic (Coman, Țîru, MeseșanSchmitz, Stanciu \& Bularca, 2020) found some teachers lacked the digital skills to perform some LMS functions as students from the survey reported $84 \%$ teachers only used basics tools on the platform. The study concluded with the importance of teacher training programs in order to adapt to virtual classes in higher education. As previously mentioned, direct feedback on the LMSs' functions can enhance student's performance, but the opposite can hinder it. It can be difficult for instructors to explain every detail to all of his or her students individually, especially if the class size is large. A repercussion of this may lead students to lack understanding and prevent them from successfully completing the course (Hetsevich, 2017).

Despite all the previous research which has been reported in this field, it is clear, education is having to continue under a unique set of circumstances which have never been experienced before. At this time, LMSs have become the only method to accommodate online learning for all classes, including English at Korean universities. Hence, given the current situation, further research is needed into the perceptions of English teachers at Korean universities towards LMSs. Consequently, this study will attempt to answer the following research questions:

1. How satisfied were English teachers at Korean Universities with using LMSs during COVID-19?

2. How prepared did English teachers at Korean Universities feel they were to use LMSs during COVID-19?

3. What did English teachers like and dislike about using LMSs during COVID-19?

\section{Method}

\subsection{Participants and Research Context}

The data for this study was collected between February $15^{\text {th }}$ and March $1^{\text {st }}, 2021$. Initially, colleagues of the authors, working in the same department, were asked to voluntarily participate. Following this, in order to get the largest range of data possible, friends and acquaintances who work as English teachers at different universities were also contacted and asked to be part of this study. They were also asked if they would be willing to share the survey link with other members of their faculty.

In total, 22 people responded to the survey and 14 $(63.6 \%)$ were male and $8(36.4 \%)$ were female. $16(72.7 \%)$ 
of the participants indicated they were aged between 36 and 45 , four (18.1\%) were aged between 46 and 55 and the remaining two were aged between 31 and 35 . The participants came from a number of different countries; six $(27.3 \%)$ are from Canada, five $(22.7 \%)$ are from Korea, three (13.6\%) from both Great Britain and Ireland, two $(9.1 \%)$ from New Zealand, two (9.1\%) from the USA, and one (4.5\%) from South Africa.

Four of the participants $(18.2 \%)$ indicated they have a bachelor's degree, 12 (54.5\%) have a master's degree and the other six $(27.3 \%)$ have a doctorate degree. Twenty out of twenty-two $(90 \%)$ have been working as English teachers for more than 11 years with 18 (81.8\%) specifying they had been working in a university setting for between six and 15 years.

They all work at nine different universities in the greater Seoul area teaching a combination of mandatory and elective courses which generally focus on the four main skills of language. All participants said more than $80 \%$ of their classes were done online since the onset of the pandemic with $16(72.2 \%)$ saying all their classes over the past year were conducted remotely. All participants used an LMS to manage their online classes and on a Likert scale out of 10, 16 (72.2\%) selected three or lower when describing how experienced they were with teaching classes online prior to March 2020.

\subsection{Data Collection}

The primary source for the data was a questionnaire (Appendix A) which was developed by the research team in late January 2021. It was subsequently created on Google Forms which was distributed via digital link for the participants to voluntarily open and complete in their own time. There were 37 questions in total, of which the first 10 were related to demographic information. The remaining item consisted of a combination of multiple choice, Likert scales and open-ended questions. Due to the nature of some of the items on the questionnaire questions, it was not possible to run a reliability test on all of them. However, for the 4 questions which focused on overall satisfaction of the LMS, a Cronbach Alpha test revealed a reliability score of 0.87 .

At the end of the data collection period, the results of the survey were collated in an Excel spreadsheet for analysis. The final question of the survey asked participants if they would be willing to be contacted to discuss some of their responses in more detail. Those who positively responded to this question were asked to leave their email address. During the data analysis phase of this study, any responses deemed pertinent to the research questions were followed up on and discussed via email / online video call.

\subsection{Data Analysis}

Once all data had been collected, it was automatically collated into an Excel spreadsheet by Google. The researchers individually organized and interpreted the responses from the participants to a Likert scale, Yes/No and multiple-choice questions and analyzed them using descriptive statistics. For the open-ended questions and personal correspondence, general qualitative data analysis was applied to identify and understand frequent trends and connections in the textual data. For example, the data collected from survey questions 15,18 , and 26, which are all open ended, was examined collectively by the research team and similar responses were grouped and collated into overarching topics to be discussed. Following this, the two sets of data were compared, and common themes and patterns were established. The researchers met via a Zoom conference call for 1 hour each day on three consecutive days in mid-March to compare thoughts and ideas. Discussions were held to resolve any discrepancies and finalize the overall results and implications. 


\section{Results and Discussion}

\subsection{Perceived Satisfaction with LMS}

To attempt to answer research question 1, the participants were asked to respond to several questions based on their experience of the LMS during the pandemic. These questions were designed to try to better understand the participants' overall satisfaction levels as well as their feelings regarding specific aspects of the LMSs.

Prior to this situation, not everyone had experience of using an LMS with six (27.3\%) out of the 22 participants indicating no previous experience. The remaining 16 instructors $(72.7 \%)$ all had experience with an LMS, although interestingly, they all appeared to use the LMS for basic administrative tasks such as sharing class documents and posting deadlines and assignments (Survey Question 15). Participants' responses to this question are collated in $<$ Table $1>$.

This data indicates those with previous experience of using an LMS used it in conjunction with face-to-face classes. They used the LMS simply as a place to store information which the students could access if they needed to, rather than as a medium of instruction and regular interaction. Arguably, the onset of COVID-19 drastically changed how the participants would use the LMS and how they would implement it into their classes.

At the beginning of the pandemic, the choice of LMS was varied and there were only minor patterns shown in the data. Six (27.3\%) of the participants used Google Classroom, eight (36.4\%) indicated the LMS was integrated into their respective universities' website, and the remaining participants used other standalone LMSs, such as Canvas, Moodle, Edmodo and Blackboard. In terms of how the participants selected the LMS (Survey Question 17), seven $(31.8 \%)$ of the participants had free choice to select any LMS they wished. The same number was given no choice and were told by their respected universities to use a specific LMS. However, eight (36.4\%) instructors had an LMS recommended by the university; however, its use was not mandatory.

When asked about their feelings about this (Survey Question 18), there were somewhat mixed reactions, but the majority of the comments were generally positive. For instance, participant B said, "It wasn't a problem, it was easy to use and everything was there." Participant $\mathrm{P}$ stated "I used Canvas and it was very easy and intuitive to use. I actually very much liked it." and participant $\mathrm{F}$ mentioned "It was easy to navigate and allowed me to upload assignments to multiple classes at once". Other comments were negative with participant $\mathrm{H}$ commenting "Not happy at first because the university servers were unprepared for the volume of traffic. This led to frequent LMS crashes in the first month of the semester."

Interestingly, 12 out of the $15(80 \%)$ participants who were given some choice over the LMS they used responded positively to this question and comments included "Great, more than enough assistance and information was provided" (Participant S) and "It was nice to have a bit of freedom and not be forced into learning a system I did not know" (Participant O). Another interesting data point was the idea that the participants enjoyed having freedom to choose the LMS with a number of comments reflecting the one of participant $\mathrm{O}$ above.

Somewhat surprisingly, the majority of participants who were given no choice of LMS also typically, had positive feelings. "It was fine" (Participant U), "Blackboard was very good. Had all the necessary functions..."

〈Table 1〉 The Main uses of LMS Prior to the Pandemic

\begin{tabular}{c|c|c} 
Primary Use & $\mathrm{n}$ & \multicolumn{1}{c}{$\%$} \\
& Share class documents and information & 11 \\
\hline Share homework content and deadlines & 4 & $25 \%$ \\
\hline Share grading information & 1 & $6.25 \%$ \\
\hline
\end{tabular}


(Participant A) and "Good, as I had some experience with it' (Participant I). A few participants seemed to have indifferent feelings towards this question and comments included, "Moodle is limited but good enough for my needs." (J) and "Ideally, I would've liked some choice, but it was more important students were comfortable with the system in use. This was easier to achieve since they used the same system in other classes. However, I was not as familiar with the system as I would've liked to have been and there didn't seem to be an ideal level of support available for me.” (E).

Given the unique set of circumstances in place due to the pandemic, with online classes being implemented at relatively short notice prior to the start of the 2020 semester, there appears to be one key data point with regards to research question 1. Despite these circumstances, the vast range in participants' demographic information, teaching experience, level of education, and previous experience with using an LMS, the overall satisfaction levels were unexpectedly high. In response to survey question 19, on a scale of one to ten, 21 instructors (95.4\%) gave a satisfaction level of six or above. Out of these 21 instructors, two gave 10 out 10, three gave nine out of ten, eight gave eight out of ten and the remaining eight instructors gave six or seven out of ten. There was only one instructor who scored below six. The results of this question can be seen in [Figure 1].

Further to this, most instructors were pleased with the overall design and interface of their LMSs (Survey
Question 20), with all but one scoring between six and nine out of ten. In addition, most participants were very satisfied with the LMS's range of functions (Survey Question 21). Over half of them (54.5\%) gave a score of eight, nine or ten out of ten, nine participants (40.9\%) scored either six or seven out of ten with one participant giving a five out of ten. Survey question 23 asked the participants if they felt the LMS was an efficient use of their time with $21(95.4 \%)$ responding positively. As the instructors' satisfaction levels were generally seen as positive, 19 of them $(86.4 \%)$ would continue to use the same LMS if classes were to continue online in the future (Survey Question 22). Only 3 participants (13.6\%) said otherwise.

\subsection{Readiness for LMS Use}

Following on from examining satisfaction levels, the second aim of this study was to try to gauge how prepared English teachers at Korean universities felt they were for using an LMS as a primary interface between teachers and students. To do this, the participants were asked to respond to survey questions based on their perceived readiness and training. One interesting point concerning this, is there was no correlation between the LMS which the participants used and their response to these questions. Even though there were multiple different LMSs used, in general the data shows participants giving the same overall comments and answers. There was an almost equal

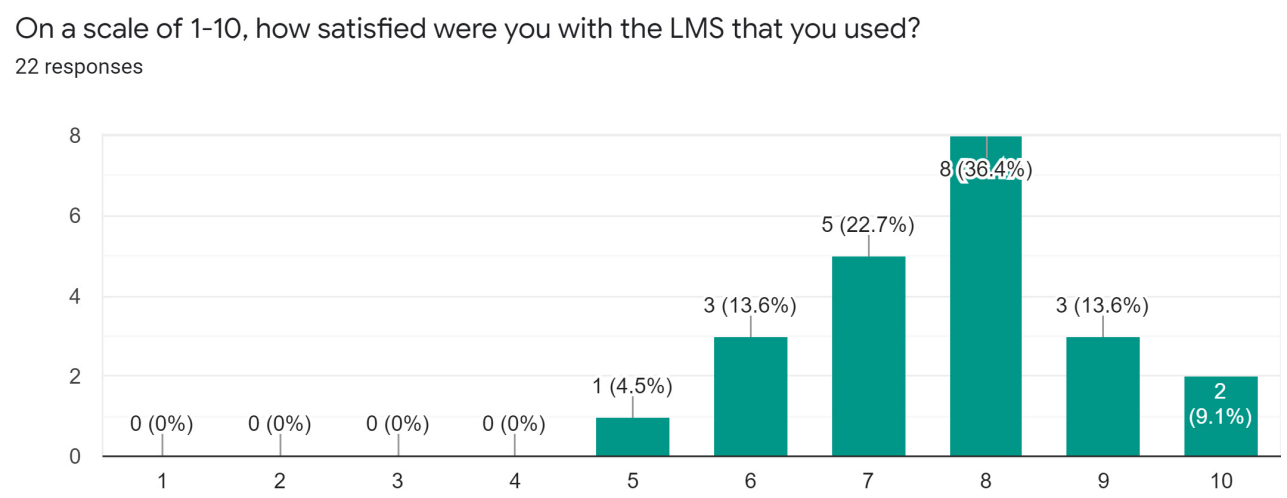

[Figure 1] Overall Satisfaction levels with the LMS used for online classes 
split between those participants who said they received formal training on how to use their chosen LMS (Survey Question 24) with 12 out 22 (54.5\%) indicating they were not provided with any training and the remaining 10 $(45.5 \%)$ saying they were offered training.

Of the 12 who did not receive any training, all but one said the self-learning was part of how they managed to learn to use the LMS, the other respondent indicated they used YouTube as a learning resource (Survey Question 25). Help from a friend or colleague was also selected as a way of understanding how to use the LMS by six of the 12 . When asked to comment on how they felt about not being offered any training (Survey Question 26) only three of the 12 participants responded positively. Amongst the remaining 12 there appears to be feelings of frustration of not knowing how to use the LMS efficiently with participant V commenting "I had used it before but not on this scale, I knew how most of it worked but a bit of training on the more complex functions would have helped." A further point of frustration seems to be a lack of multi-language navigation being available with several participants commenting on their ability to use the LMS was limited by not having English menus, buttons and functions available. Despite these feelings of frustration, there also appears to be empathy with the unique circumstances and having no choice to use an LMS. Participant B commented using the LMS "Was difficult but understandable that suddenly being online was a tough transition", several other comments echoed this sentiment. One interesting point is more than half $(58.8 \%)$ of those who were not provided with any training felt it took longer than one week to feel comfortable using an LMS for their classes, with some of those participants saying it would take longer than 2 weeks to feel they were ready. This is a significant amount of time considering a typical semester in this context is 15 weeks long (Survey Question 27).

For those who did receive training, the majority of the ten indicated they felt it was effective with seven (70\%) scoring seven or higher on a 10-point scale (Survey Question 28). LMS training which was given was completed in a number of different ways as indicated in $<$ Table $2>$ (Survey Question 29).

There appeared to be a clear pattern in what aspects of LMS' usage the participants found the training helped with (Survey Question 30). The data indicates they felt better able to share class materials, set up homework assignments, provide feedback, and respond to student enquiries after having received training. They did not find the training particularly beneficial in terms of preparing class materials, grading, and online storage space which could indicate that even though classes were being taught online and in unusual circumstances, the participants still felt confident in their ability to teach and prepare effective class materials. The data from this question is summarized in $<$ Table $3>$ below.

Overall, those who were trained did feel it helped them to use the LMS; whereas those who were not trained seemed to feel they would have benefited from formal training. This idea is backed up by personal communications between the research team and two of the participants who did not receive any training. Participant F commented "I have been using LMS for a few years, but I am still finding out features that are available now, so training would have helped me use it more effectively from the start". A similar point arose in a discussion with participant A with he/she commenting that training on all the functions would have been very helpful.

〈Table 2〉 How LMS Training was Delivered

\begin{tabular}{|c|c|c|}
\hline How was LMS Training Delivered & $\mathrm{n}$ & $\%$ \\
\hline Live Online Workshops (Zoom, Google Meet) & 7 & $70 \%$ \\
\hline Written Instructions (Pdf, Word Documents) & 5 & $50 \%$ \\
\hline Video / Audio Instructions (Pre-recorded Videos, YouTube, Podcast, Audiobook) & 4 & $40 \%$ \\
\hline Other (Telephone Helpline) & 1 & $10 \%$ \\
\hline
\end{tabular}


〈Table 3〉 How Training Helped with LMS Use

\begin{tabular}{c|c|c} 
Function that training helped with & $\mathrm{n}$ & $\%$ \\
Setting assignments, quizzes, and exams & 8 & $80 \%$ \\
\hline Sharing class materials & 7 & $70 \%$ \\
\hline Providing feedback to students & 5 & $50 \%$ \\
\hline Handling student requests and questions & 4 & $40 \%$ \\
\hline Grading & 3 & $30 \%$ \\
\hline Online storage space & 2 & $20 \%$ \\
\hline Preparing and creating class materials & 1 & $10 \%$ \\
\hline Other: Improving intonation when speaking and student psychology & 1 & $10 \%$ \\
\hline
\end{tabular}

\subsection{Perceived Likes and Dislikes of LMSs}

The final research question of this study was designed to try to better understand what teachers liked and disliked about using LMSs for teaching English. In order to do this, the process of teaching a class was broken down into three components of class management, content preparation and delivery, and assessment. The participants were then asked their feelings on how well the LMS could handle each of these (Survey Question 32, 33, 34).

In terms of class management, there appears to be a direct correlation with the perceived strong points of the LMS and the specific area of English the participants taught. Prior to answering these three questions, participants were asked to indicate the general focus of the classes they taught (Survey Question 31). The more communicative skills of speaking and writing were most commonly chosen with $21(95.5 \%)$ selecting speaking and 14 (63.3\%) selecting writing. Significantly, every participant whose classes were speaking or writing based commented that being able to provide feedback to students or being able to message students directly from the LMS was a clear benefit. This idea seems to reflect what might happen in a face-to-face class during which the teacher provides individual or group feedback on class activities or tasks; thus, English teachers appear to still believe providing feedback to students remains important, even if classes are online.

In terms of content preparation, delivery, and sharing the link between the subjects taught and positive points of the LMS is not as obvious. Regarding this aspect of teaching a class, the participants seemed to feel the ability to edit previously posted class information and the ability to preview materials prior to posting were well liked. They also appeared to feel having plentiful online storage space and the ability to bulk upload or share materials to multiple classes at the same time are also important, possibly signaling the LMS is an efficient use of their time. However, having the ability to share content with other teachers either using the same or different LMS was not deemed as being useful which is somewhat surprising given that being able to import / export materials is an effective way to save time. The data from question 33 is summarized in $<$ Table $4>$.

With regards to student assessment, the data indicates two main positive features of an effective LMS. First of all, having a built-in gradebook to record assignment and exams scores is viewed as important with 15 out of 22 $(68.2 \%)$ selecting this option in survey question 34 . The same number of participants selected having an LMS which allows teachers to grade assignments directly on the system without having to download or use another interface. It could be argued these results are also related to the idea of having an LMS which is an efficient use of time, as discussed in the previous paragraph. Other, less commonly chosen, merits related to student assessment were the ability to preview assignments (36.4\%), having a gradebook which was easy to use (36.4\%), and the ability to share assignment / exam scores with students $(31.8 \%)$. 
Perceptions of English Teachers at Korean Universities Towards using Learning Management Systems During COVID-19

〈Table 4〉 Perceived LMS Likes and Dislikes with Regards to Content Preparation, Delivery, and Sharing

\begin{tabular}{|c|c|c|}
\hline Functions / Features & $\mathrm{n}$ & $\%$ \\
\hline Ability to edit information (homework / class information, submission deadlines) after posting & 12 & $54.5 \%$ \\
\hline Ability to preview materials / homework before assigning them & 11 & $50 \%$ \\
\hline Plentiful storage space & 7 & $31.8 \%$ \\
\hline Ability to bulk upload / share information to multiple classes at the same time & 7 & $31.8 \%$ \\
\hline Ability to import / export class materials to / from other classes on the LMS & 6 & $27.3 \%$ \\
\hline Ease in importing / exporting content to / from other classes on the LMS & 5 & $22.7 \%$ \\
\hline Ability to share content with other teachers who use the same LMS & 4 & $18.2 \%$ \\
\hline None of the above & 2 & $9.1 \%$ \\
\hline Ease in sharing content with other teachers & 1 & $4.5 \%$ \\
\hline Ease in sharing content with other teachers who use a different LMS & 0 & $0 \%$ \\
\hline Ability to share content with teachers who use a different LMS & 0 & $0 \%$ \\
\hline Other (Please Specify) & 0 & $0 \%$ \\
\hline
\end{tabular}

〈Table 5〉 LMS limitations in Terms of Class Management.

\begin{tabular}{c|c|c} 
Class management limitations & $\mathrm{n}$ & $\%$ \\
None of the above & 8 & 38.1 \\
\hline Difficulty in putting students in small groups & 5 & $23.8 \%$ \\
\hline Inability to see the student version of the system & 3 & $14.3 \%$ \\
\hline Inability to see student's registration information and contact details & 2 & $9.5 \%$ \\
\hline Inability to send messages to individual students & 2 & $9.5 \%$ \\
\hline Inability to record class attendance & 2 & $9.5 \%$ \\
\hline Inability to see student's registration information and contact details & 2 & $9.5 \%$ \\
\hline Inability to record student class attendance & 2 & $9.5 \%$ \\
\hline Inability to provide general feedback to an entire class & 1 & $4.8 \%$ \\
\hline Inability to send bulk messages to a whole class & 1 & $4.8 \%$ \\
\hline Other, please specify & 0 & $0 \%$ \\
\hline
\end{tabular}

Following this, the participants were asked about any limitations and drawbacks of their chosen LMS with regard to the same three components of class management, content preparation and delivery, and assessment (Survey questions 35, 36, 37). Concerning survey question 35 which asked about limitations for class management, eight (38.1\%) participants stated there were no limitations with their LMS. However, one standout limitation, which five (23.8\%) participants mentioned, was difficulty to put students into groups. This would be a concern, as the majority of participants were teaching speaking classes, during which students are commonly split into groups for speaking activities that would be relatively easy to carry out in a classroom setting. The second biggest limitation that three $(14.3 \%)$ participants remarked on was the inability to see the students' version of the LMS. Other limitations which participants commented on are seen in $<$ Table $5>$ below.

Continuing with limitations regarding content preparation (survey question 35), five (22.7\%) participants stated their LMSs lacked the ability to bulk upload material and share information to multiple classes at the same time. Likewise, another five participants added they had difficulty in importing exporting content to / from other classes on the LMS. Furthermore, four participants noted their LMS lacked the ability to share content with other teachers who use a different LMS. Again, emphasizing the importance of using LMSs to be an effective use of their time. Nevertheless, there were seven $(38.1 \%)$ participants who responded positively and stated they were content with 
their LMS by declaring no limitations.

Survey question 36 dealt with limitations for student assessment. Surprisingly, over half of the participants $(60 \%)$ felt there were no issues regarding assessment functions. The major concern for five participants (25\%) was their particular LMS had difficulty in using the gradebook to track student progress, while two participants' LMSs lacked suitable homework and assignment options and a further two participants noted they couldn't test and preview assignments before showing them to the class.

\section{Conclusion and Implications}

This research was undertaken given the unique, never experienced before, circumstances brought on by the COVID-19 pandemic. Whilst there have been previous studies that examined similar aspects of LMS use, very few, if any, will have been completed during a pandemic of the scale and seriousness of the current one hence the need for this research to be undertaken. From the research findings and the importance of LMS systems may have in education in the future, there are several possible pedagogical implications brought about by this study. First is the significance of LMS training to help teachers use the full potential of its functions. Moreover, this study could provide useful information to university's administration departments to select the most effective LMS. Finally, this paper may give a better understanding to LMS developers about the required functions and features needed for a successful LMS system for EFL teachers.

There are a number of implications and conclusions to be drawn for each research question. First of all, despite the great upheaval caused by a sudden change in how English classes at Korean universities were conducted, teachers in this context seem to be able to quickly adapt to having to suddenly use an LMS as their main teaching medium. Regardless of background, experience, training, and education, teachers generally found it straightforward to make the transition to online classes and overall satisfaction levels were high, which aligns with the results of other studies (Basal, 2015; Hooser, 2018). One interesting find, regarding the first research question, is teachers seemed to prefer having a choice of which LMS to use rather than being forced into using one they are not familiar with; however, this does not appear to be essential and satisfaction levels are not significantly impacted if no choice is given.

Secondly, LMS training which has been provided so far seems to be useful for specific skills. Those who received some training seemed to have found it beneficial. Despite this, there appears to be a desire for more training for both basic and more complex functions offered by LMS. Whilst the immediacy of the situation is acknowledged, there may not have been sufficient time or resources to set up training sessions or materials. However, moving forward, with the pandemic seemingly far from being over, university administrations may consider developing and improving LMS training programs to help improve English teachers LMS proficiency. In addition, teachers' ability to use the LMS seems to have been impacted by either the language provided during training and / or the language used in the LMS interface. Consequently, providing multi language training or providing an LMS with customizable language settings is something administrations may consider in the future.

A further implication relates to the specific functions provided by an LMS. It appears language teachers have a desire for the LMS to mirror a face-to-face class as much as possible. There is a need for them to be able to contact the students and provide feedback about their performance, just as they would in a regular class. Furthermore, given that in face-to-face language classes, students will often be working in small groups, particularly in speaking-based classes, having the ability to quickly place learners into small breakout groups is a function which needs to be carefully considered for future LMS systems. While many LMSs currently provide these capabilities, it is important these functions are maintained and possibly improved. 
A final implication is LMSs are as time efficient as possible. The sudden move to online classes undoubtedly created a substantial amount of extra work for teachers, including creating materials and recording videos. Having an LMS which allows teachers to bulk upload work to multiple classes, bulk message students, preview work, and easily grade students' work appears to be critical and university administration and/or LMS providers need to be aware of this when choosing/designing systems of the future.

In summary, given that LMSs could potentially play a more significant role in English education in the future, the potential pedagogical implications discussed in this study could contribute to how LMS system are selected by universities, how LMS training of the future could be conducted, and how LMS designers integrate functions and features that will work in LMS based EFL classes of the future.

\section{Limitations}

Although this research has revealed a number of interesting data points regarding how English teachers at Korean universities felt about using an LMS during the pandemic, the researchers are aware of the limitations of this study. While attempts were made to gather the widest range of data as possible, only 22 respondents to the survey questionnaire are not enough to get a suitable cross-section of English teachers working at all Korean universities. A bigger study with much broader sample size would be needed and could possibly be considered in the future. Furthermore, another major limitation of the study is the data clearly shows the participants all used different LMSs, with some also using more than one. This meant it was difficult to report on the research questions in terms of one specific LMS. Instead, this project was able to gather data about LMSs in general rather than each specific LMS. More research focusing on each one individually would be needed and could potentially yield slightly different results. Finally, the majority of the data came from multiple choice or short answer questions and a more in-depth qualitative approach including interviews and / or discussion groups could potentially reveal findings not obvious during this study.

\section{References}

Al-Busaidi, K. A., \& Al-Shihi, H.(2012). "Key factors to instructors' satisfaction of learning management systems in blended learning", J Comput High Educ 24, 18-39. https://doi.org/10.1007/s12528-011-9051-x

Back, D., Kalenzi, C., \& Yim, M.(2020). "The future of online education: Lessons from South Korea", World Economic Forum, https://www.weforum.org/agenda/2020/11/lessons -from-south-korea-on-the-future-of-online-education/

Başal, A.(2015). "Perceptions of pre-service English teachers towards the integration of an LMS into English language teacher education", Journal of Technology and Teacher Education 23, 485-507.

Bervell, B., \& Umar, I.(2018). "Blended learning or face-to-face? Does tutor anxiety prevent the adoption of learning management systems for distance education in Ghana?", Open Learning: The Journal of Open, Distance and e-Learning 35, 1-19. 10.1080/02680513.2018.1548964

Bouchrika, I.(2020). "List of learning management systems for schools and universities", Guide2Research, Retrieved from: https://www.guide2research.com/research/list-of-learningmanagement-systems-for-schools-and-universities

Brooks, D. C., \& Pomerantz, J.(2017). "ECAR Study of Undergraduate Students and Information Technology", Research report, Louisville, CO: ECAR.

Butakov, S., Solodky, O., \& Swar, B.(2013). LMS implementation in startup institutions: Case study of three projects: learning management systems and instructional design: Best practices in online education (pp. 40-54), IGI Global.

Cabral, P. B., Pedro, N., \& Gonçalves, A. M.(2012). "LMS in higher education: analysis of the effect of a critical factor 'faculty training", World Academy of Science, Engineering and Technology 66, 613-618.

Chaubey, Aabha, \& Bhattacharaya, Bani(2015). "Learning management systems in higher education", International Journal of Science Technology \& Engineering 2(3), 158-162.

Cheok, M., \& Wong, Su(2015). "Predictors of e-learning satisfaction in teaching and learning for school teachers: A literature review", International Journal of Instruction 8, 75-90.

Coman, C., Țîru, L. G., Meseșan-Schmitz, L., Stanciu, C., \& Bularca, M. C.(2020). "Online teaching and learning in 
higher education during the coronavirus pandemic: Students' perspective", Sustainability 12(24), 10367. https://doi.org/1 $0.3390 / \mathrm{su} 12241036712$

Dias, S. B., Hadjileontiadou, S. J., Diniz, J. et al.(2020). "Deep LMS: a deep learning predictive model for supporting online learning in the COVID-19 era", Sci Rep 10, 19888. https://doi.org/10.1038/s41598-020-76740-9

Dodds, W.(2019). "Disease now and potential future pandemics", The world's worst problems, 31-44. https://doi.org/10.1007/ 978-3-030-30410-2 4

Epping, R. J.(2010). "Innovative use of blackboard [R] to assess laboratory skills", Journal of Learning Design 3(3), 32-36.

Hill, P.(2017). State of higher ed LMS market for US and Canada: Spring 2017 edition [Blog post]. Retrieved from: http://mfel dstein.com/state-higher-ed-lms-market-us-canadaspring-2 017-edition

Holmes, K. A., \& Prieto-Rodriguez, E.(2018). "Student and staff perceptions of a learning management system for blended learning in teacher education", Australian Journal of Teacher Education 43(3), http://dx.doi.org/10.14221/ajte.2018v43n3.2

Jenkins, M., Browne, T., Walker, R., \& Hewitt, R.(2010). "The development of technology enhanced learning: Findings from a 2008 survey of UK higher education institutions", Interactive Learning Environments 19, 447-465. doi:10.108 0/10494820903484429

Jurado, R. G., Pettersson, T., Gómez, A. R., \& Scheja, M.(2014). "Classification of the features in learning management systems", In proceedings of: 17th Scientific Convention on Engineering and Architecture, November 24th-28th, 2014, Havana International Conference Center.

Karunaratne, T., Zhemchugova, H., Byungura, J. C., \& Olsson, U.(2019). "Towards an agile-based process model for effective teacher training on LMS", Conference: 18th European Conference on e-Learning. At: Copenhagen, Denmark. November 7th-8th, 2019, Aalborg University, Copenhagen, Denmark, doi:10.34190/EEL.19.099

Klobas, J. E., \& McGill, T. J.(2010). "The role of involvement in learning management system success", Journal of Computing in Higher Education 22(2), 114-134. http://doi. org/10.1007/s12528-010-9032-5

Maske, P.(2020). "Importance of LMS software during COVID-19 pandemic", Education, Paradiso News, https://www.paradi sosolutions.com/blog/importance-lms-software-covid-19pandemic/

Paulsen, M. F.(2003). "Experiences with learning management systems in 113 European institutions", Educational Technology \& Society 6(4), 134-148.

Rhoads, M., \& Stachowiak, B. (Eds).(2017). Igniting your teaching with educational technologies: A resource for new teachers, Ladera Ranch, CA: Innovate Learning LLC.
Rhode, J., Richter, S., Gowen, P., Miller, T., \& Wills, C.(2017). "Understanding faculty use of the learning management system”, Online Learning 21(3) 68-86. doi:10.24059/olj.v\% vi\%i.1217

Rienties, B., \& Townsend, D.(2012). "Integrating ICT in business education: Using TPACK to reflect on two course redesigns", In P. Van den Bossche, W. H. Gijse-laers, \& R. G. Milter (Eds.), Learning at the crossroads of theory and practice 4 (pp. 141-156), Dordrecht: Springe.

Turnbull, D., Chugh, R., \& Luck, J.(2019). "Learning management systems: An overview”, In A. Tatnall (Ed.), Encyclopedia of Education and Information Technologies, Springer, Cham, https://doi.org/10.1007/978-3-319-60013-0_248-1

Ushakov, A.(2017). "Learning content management systems in Flt: Canadian experience", International Journal of English Language and Literature Studies 6(1), 25-32.

Weaver, D., Spratt, C., \& Nair, C. S.(2008). "Academic and student use of a learning management system: Implications for quality", Australasian Journal of Educational Technology 24(1), 30-41.

Wulandari, Putri, \& Budiyanto, Cucuk(2017). "Improving foreign language learning by the mean of learning management system: Review of the literature", Advances in Social Science, Education and Humanities Research 158.

Zawacki-Richter, O.(2020). "The current state and impact of COVID-19 on digital higher education in Germany", Human Behavior \& Emerging Technologies 1(9), 218-226.

Armstrong, S.(2013). "Advantages and disadvantages of online learning”, eLearning Industry, Retrieved from http://elearni ngindustry.com/advantagesanddisadvantagesofonlinelearn ing

Bahk, E. J.(March 2020). "College students unhappy with online lectures", The Korea Times, http://www.koreatimes.co.kr/w ww/nation/2020/03/\%20113_285496.html

Educause Learning Initiative(2015). "7 things you should know about NGDLE", Retrieved from https://ibrary.educause.ed u/ /media/files/library/2015/12/eli7127-pdf.pdf

Hetsevich, I.(2017). "Advantages and disadvantages of E-learning technologies", Retrieved from: Advantages and Disadvantages of E-Learning Technologies for Students.

Hooser, A.(2018). "Teacher satisfaction drives learning management styles", Retrieved from: Satisfaction with LMS Functionality | EDUCAUSE.

Sharma, A.(2017). "The history of distance learning and the LMS", Retrieved from https://elearnhub.org/the-history-ofdistance-learning-and-the-lms/

University of Colorado, Boulder(2016). "LMS evaluation and selection project faculty survey report", Retrieved from https://www.colorado.edu/lms/sites/default/files/attached-f iles/lms_eval-fac_0.pdf 


\section{Appendix A}

1. Gender (Mark only one oval)

O Male

O Female

2. Age (Mark only one oval)
O 20-25
O $26-30$
O $31-35$
O $36-40$
O 41-45
O $51-55$
O $56-60$
O $61-60$

3. Nationality (Mark only one oval)

O Korean

O British

O American

O Canadian

O Australian

O New Zealand

O South African

O Irish

O Other

4. What is the highest level of formal education you have attained? (Mark only one oval)

O Bachelor's Degree
O Master's Degree
$\mathrm{O}$ Doctorate $(\mathrm{PhD})$

5. What is the name of the university you work at?

Please answer the following questions about your teaching experience.

6. How many years have you been working as an English teacher (Mark only one oval)
O 1-5 years
O 6-10 years
O 11-15 years
O $16-20$ years 

O 21-25 years
O 26-30 years
O 31-35 years
O $35+$ years

7. How many years have you been working as an English teacher at a university?
O $1-5$ years
O 6-10 years
O $11-15$ years
O 16-20 years
O 21-25 years
O 26-30 years
O 31-35 years
O $35+$ years

8. Please specify if the classes you teach are mandatory or optional?
O Mandatory
O Optional
O Both

9. What is the general focus of the classes you teach (Select all options that apply)
O Speaking
O Writing
O Reading
O Listening
O Presentations
O Other

10 In general, in what year of their studies are the students that you teach? (Select all options that apply)

O Freshman (Year 1)

O Sophomore (Year 2)

O Junior (Year 3

O Senior (Year 4)

O Graduate

11. Prior to March 2020, how experienced would you say you were with teaching English classes online (Mark only one oval)

$\begin{array}{llllllllllll}\text { Highly inexperienced } & 1 & 2 & 3 & 4 & 5 & 6 & 7 & 8 & 9 & 10 & \text { Highly experienced } \\ & \mathrm{O} & \mathrm{O} & \mathrm{O} & \mathrm{O} & \mathrm{O} & \mathrm{O} & \mathrm{O} & \mathrm{O} & \mathrm{O} & \mathrm{O} & \end{array}$


12. Over the past 1 year, approximately what percentage of the classes you taught were conducted online? (Mark only one oval)

O $20 \%$

O $40 \%$

O $60 \%$

O $80 \%$

$\mathrm{O} 100 \%$

13. Over the past year, did you use an LMS to organize and manage classes? (Mark only one oval)

$\mathrm{O}$ Yes

O No

14. Had you ever used an LMS for your classes prior to 2020? If yes, which ones? (Select all options that apply)

O Google Classroom

O Canvas Microsoft

O Teams

O Edmodo

O Moodle

O Blackboard

O The LMS was integrated into the university's website

O University LMS system integrated with a 3rd party LMS

O I have never used one

O Other

15. If you have used one prior to 2020, what functions on that LMS did you mostly use for your classes?

16. What was the LMS you predominantly used during online classes in 2020? (Mark only one oval)

O Google Classroom

O Canvas Microsoft

O Teams

O Edmodo

O Moodle

O Blackboard

O The LMS was integrated into the university's website

O University LMS system integrated with a 3rd party LMS

O I used more than one

O Other 
17. How did you select which LMS to use? (Mark only one oval)

O I was free to select any LMS I wished

O The LMS was recommended by my university but using it was not mandatory

O I was given no choice, my university told me which LMS I had to use

18. How did you feel about this and why?

19. On a scale of 1-10, how satisfied were you with the LMS you used? (Mark only one oval) $\begin{array}{llllllllllll}\text { Very dissatisfied } & 1 & 2 & 3 & 4 & 5 & 6 & 7 & 8 & 9 & 10 & \text { Highly satisfied }\end{array}$ $\begin{array}{lllllllllll}\mathrm{O} & \mathrm{O} & \mathrm{O} & \mathrm{O} & \mathrm{O} & \mathrm{O} & \mathrm{O} & \mathrm{O} & \mathrm{O} & \mathrm{O}\end{array}$

20. On a scale of 1-10, how would you rate the design and interface of the LMS you used? (Mark only one oval)

$\begin{array}{llllllllllll}\text { Very poor } & 1 & 2 & 3 & 4 & 5 & 6 & 7 & 8 & 9 & 10 & \text { Excellent }\end{array}$

$\begin{array}{lllllllllll}\mathrm{O} & \mathrm{O} & \mathrm{O} & \mathrm{O} & \mathrm{O} & \mathrm{O} & \mathrm{O} & \mathrm{O} & \mathrm{O} & \mathrm{O}\end{array}$

21. On a scale of 1-10, how satisfied were you with the range of functions provided by the LMS? (Mark only one oval)

$\begin{array}{llllllllllll}\text { Very dissatisfied } & 1 & 2 & 3 & 4 & 5 & 6 & 7 & 8 & 9 & 10 & \text { Highly satisfied }\end{array}$

$\begin{array}{llllllllll}\mathrm{O} & \mathrm{O} & \mathrm{O} & \mathrm{O} & \mathrm{O} & \mathrm{O} & \mathrm{O} & \mathrm{O} & \mathrm{O} & \mathrm{O}\end{array}$

22. Given the option, would you continue to use the same LMS if classes continue online in the future?

(Mark only one oval)

$\mathrm{O}$ Yes

O No

23. On a scale of 1-10, would you say using the LMS was an efficient use of your time? (Mark only one oval) $\begin{array}{llllllllllll}\text { Very inefficient } & 1 & 2 & 3 & 4 & 5 & 6 & 7 & 8 & 9 & 10 & \text { Very efficient }\end{array}$ $\begin{array}{lllllllllllllll}\mathrm{O} & \mathrm{O} & \mathrm{O} & \mathrm{O} & \mathrm{O} & \mathrm{O} & \mathrm{O} & \mathrm{O} & \mathrm{O} & \mathrm{O}\end{array}$

24. Were you offered any training on how to use the LMS either before online classes started or during the semester in 2020? (Mark only one oval)

$\mathrm{O}$ Yes

$\mathrm{O}$ No

25. How did you learn to use the LMS? (Select all options that apply)

O Self learnt

O Help from a colleague

O Help from a friend

O Other 
26. How did you find this and why?

27. How long did it take for you to feel you could effectively use the LMS for your classes?

(Mark only one oval)

O Less than one day

O 2-4 days

O 5-7 days

O 1 week

O 2 weeks

O Longer than 2 weeks

O Other

28. On a scale of 1-10, how helpful did you find the training you received? (Mark only one oval) $\begin{array}{llllllllllll}\text { Very unhelpful } & 1 & 2 & 3 & 4 & 5 & 6 & 7 & 8 & 9 & 10 & \text { Very helpful }\end{array}$ $\begin{array}{lllllllllll}\mathrm{O} & \mathrm{O} & \mathrm{O} & \mathrm{O} & \mathrm{O} & \mathrm{O} & \mathrm{O} & \mathrm{O} & \mathrm{O} & \mathrm{O}\end{array}$

29. What kind of training? (Select all options that apply)

O Live Online Workshops (Zoom, Google Meet)

O Written Instructions (Pdf, Word Document, PowerPoint File)

O Video / Audio Instruction (YouTube / Podcast / Audiobook)

O Other

30. What specifically did you find the training helped you with? (Select all options that apply)

O Preparing and creating class materials

O Sharing class materials

O Setting assignments, quizzes and exams

O Online storage space

O Handling student requests and questions

O Providing feedback to your students

O Grading

O Other

31. What is the general focus of the classes you teach? (Select all options that apply)

O Speaking

O Writing

O Reading

O Listening

O Presentations

O Other 
32. In terms of class management, which of the following functions did you find most useful?

(Select all options that apply)

O Ability to put students into small groups

O Ease in putting students in small groups

O Ability to provide specific feedback to an individual student

O Ability to provide general feedback to an entire class

$O$ Ability to send messages to individual students

O Ability to send bulk message to whole classes

$\mathrm{O}$ Ability to see students registration information and contact details

O Ability to record student class attendance

O Ability to see the student version of the system

O None of the above

33. In terms of class preparation, content delivery, and content sharing, which of the following functions did you find most useful? (Select all options that apply)

O Plentiful digital storage space

O Ability to bulk upload / share information to multiple classes at the same time

O Ability to preview materials / homework before assigning them

O Ability to edit information (homework / class information, submission deadlines) after posting

O Ability to import / export class materials to / from other classes on the LMS

O Ease in importing / exporting content to / from other classes on the LMS

O Ability to share content with other teachers who use the same LMS

O Ease in sharing content with other teachers who use the same LMS

O Ability to share content with other teachers who use a different LMS

$\mathrm{O}$ Ease in sharing content with other teachers who use a different LMS

O None of the above

34. In terms of student assessment, which of the following functions did you find most useful?

(Select all options that apply)

O Enough suitable homework / assignment functions

$\mathrm{O}$ Ability to preview and test assignments before sharing them with classes

O Ability to grade assignments / exams directly on the LMS

O Presence of gradebook to track student progress

O Ease in using the gradebook to track student progress

O Ability to share students assignment / exam scores with them

O None of the above

35. In terms of class management, which of the following would you say were the biggest limitations of the

LMS? (Select all options that apply)

O Inability to put students into small groups 
O Difficulty in putting students in small groups

O Inability to provide specific feedback to an individual student

O Inability to provide general feedback to an entire class

O Inability to send messages to individual students

O Inability to send bulk message to whole classes

$\mathrm{O}$ Inability to see students registration information and contact details

O Inability to record student class attendance

O Inability to see the student version of the system

O None of the above

36. In terms of class preparation, content delivery, and content sharing, which of the following would you say were the biggest limitations of the LMS? (Select all options that apply)

O Lack of digital storage space Inability to bulk upload / share information to multiple classes at the same time

O Inability to preview materials / homework before assigning them

O Inability to edit information (homework / class information, submission deadlines) after posting

O Inability to import / export class materials to / from other classes on the LMS

O Difficulty in importing exporting content to / from other classes on the LMS

O Inability to share content with other teachers who use the same LMS

O Difficulty in sharing content with other teachers who use the same LMS

O Inability to share content with other teachers who use a different LMS

O Difficulty in sharing content with other teachers who use a different LMS

O None of the above

37. In terms of student assessment, which of the following would you say were the biggest limitations of the LMS? (Select all options that apply)

O Not enough suitable homework / assignment options

O Inability to preview and test assignments before sharing them with classes

O Inability to grade assignments / exams directly on the LMS

O Lack of gradebook to track student progress

O Difficulty in using the gradebook to track student progress

O Inability to share students assignment / exam scores with them

O None of the above 


\section{COVID-19 중 학습관리 시스템에 대한 한국 대학 영어 교사들의 인식}

스튜어트 존스 1 , 앤드류 리차드스2, 조영상3

1단국대학교 조교수

2단국대학교 조교수

3단국대학교 부교수

초록

본 연구는 한국 대학에서 영어를 가르치는 교수자의 2020 학년도 코로나 상황 속 학습관리시스템(LMS) 사용 현황 및 인식을 파악하고자 한다. 수도권 지역 9 개의 대학에 소속되어 있는 영어 교수자 총 22 명이 본 연구에 참여하였다. 주요 연구자료로는 선다형 문항과 리커트 척도 및 개방형 질문으로 구성된 설문이 사용되었으며, 필요한 경우, 설문 참여자의 동의 하에 이메일이나 화상통화를 통한 추가 질의응답이 이루어졌다. 수집된 자료의 분석을 위해 기술통계와 질적 자료 분석 방법이 사용되었다. 연구결과에 따르면 코로나 상황에 의해 야기된 여러 문제에도 불구하고 연구 참여자들은 LMS을 본인의 주요 교수 인터페이스로 사용하는 것에 빠르게 적응하였으며, LMS 사용에 대하여서도 대체로 만족하는 것으로 나타났다. 또한 LMS 운영과 관련된 교육이 전반적으로 유익하나 부가적인 교육 또한 필요하다고 인식하고 있었다. 특히 언어 교육에 활용할 수 있는 LMS의 특정 기능에 초점을 맞춘 교육의 중요성을 언급하였다. 연구 결과를 바탕으로 본 연구의 행정적, 교육적 함의 및 한계점을 논의하였다.

주제어: 외국어로서의 영어, 코로나19, 학습관리시스템, 교양영어교육 